\title{
PENURUNAN KECEMASAN PADA PASIEN PRE OPERASI SETELAH PELAKSANAAN RELAKSASI IMAJINASI TERBIMBING DI RSUD PATUT PATUH PATJU GERUNG
}

\author{
GA Sri Puja Warnis Wijayanti ${ }^{1}$, Putu Ayu Suryantini Prasetianti ${ }^{2}$ \\ 1,2 Jurusan Keperawatan, Poltekkes Kemenkes Mataram/Indonesia
}

\begin{abstract}
ABSTRAK
Operasi/prosedur pembedahan akan memberikan suatu reaksi emosional bagi pasien. Kecemasan dapat menimbulkan adanya perubahan secara fisik maupun psikologis. Kondisi ini memerlukan suatu upaya dalam menurunkan kecemasan yaitu salah satunya teknik relaksasi imajinasi terbimbing, tindakan ini bertujuan untuk meningkatkan kendali dan rasa percaya diri serta mengurangi stres dan kecemasan yang dirasakan. Untuk mengetahui pengaruh teknik relaksasi imajinasi terbimbing terhadap kecemasan pada pasien pre operasi di RSUD Patut Patuh Patju Gerung. Penelitian ini menggunakan desain penelitian pra eksperimental dengan bentuk rancangan one group pra-post test design dengan jumlah sampel sebanyak 30 sampel dengan teknik purposive sampling. Dianalisa dengan menggunakan Uji Wilcoxon dengan tingkat signifikansi $\rho$ value $<\alpha(5 \%)$. Hasil penelitian menunjukkan sebelum dilakukan teknik relaksasi imajinasi terbimbing sebagian besar responden berada pada kategori cemas sedang $(66,67 \%)$ dan setelah dilakukan teknik relaksasi imajinasi terbimbing sebagian besar responden berada pada kategori cemas ringan $(66,67 \%)$. Ada pengaruh teknik relaksasi imajinasi terbimbing terhadap kecemasan pada pasien pre operasi di RSUD Patut Patuh Patju Gerung Tahun 2018.
\end{abstract}

Kata Kunci: Pre operasi, Kecemasan, Teknik Relaksasi Imajinasi Terbimbing

\section{THE DECREASED IN ANXIETY OF PRE OPERATIF PATIENTS AFTER THE IMPLEMENTATION OF GUIDED IMAGINATION RELAXATION AT PATUT PATUH PATJU HOSPITAL, GERUNG}

\begin{abstract}
Surgery / surgical procedure will provide an emotional reaction for the patient. Anxiety can lead to physical and psychological changes. This condition requires an effort in reducing anxiety that is one technique of guided imagination relaxation, this action aims to improve control and confidence and reduce stress and anxiety felt. To know the effect of guided imagination relaxation techniques on anxiety in preoperative patients at RSUD Patut Patuh Patju Gerung. This research used pre experimental research design with one group pre-post test design design with a total sample of 30 samples with purposive sampling technique. Analyzed by using Wilcoxon Test with significance level $\rho$ value $<\alpha(5 \%)$. The results showed $p$ enelitian before guided imagery relaxation techniques majority of respondents are in the category of moderate anxiety (66.67\%) and after the guided imagery relaxation techniques majority of respondents are in the category of mild anxiety (66.67\%). There is influence of guided imagination relaxation technique to anxiety in patient pre operation in RSUD Patut Patuh Patuh Gerung Tahun 2018.
\end{abstract}

Keywords: Pre surgery, Anxiety, Guided Imitation Technique Relaxation 


\section{PENDAHULUAN}

Pembedahan atau operasi adalah semua tindakan pengobatan yang menggunakan cara invasif dengan membuka atau menampilkan bagian tubuh yang akan ditangani. Pembukaan bagian tubuh pada umumnya dilakukan dengan membuka sayatan. Setelah bagian yang akan ditangani tampak, dilakukan tindakan perbaikan yang diakhiri dengan penutupan dan penjahitan luka (Sjamsuhidayat, 2010). Operasi memiliki tiga tahapan yaitu pre operasi, intra operasi dan post operasi. Pre operasi merupakan tahapan awal dari keperawatan perioperatif. Saat menghadapi pembedahan, klien akan mengalami berbagai stressor. Pembedahan yang ditunggu pelaksanaannya akan menyebabkan rasa takut dan kecemasan pada klien yang menghubungkan pembedahan dengan rasa nyeri, kemungkinan cacat, menjadi bergantung pada orang lain dan mungkin kematian. Ketakutan dan kecemasan yang mungkin dialami pasien dapat dilihat dari tanda dan gejala seperti: meningkatnya frekuensi jantung, gerakan-gerakan tangan yang tidak terkontrol, telapak tangan yang lembab, gelisah, menanyakan pertanyaan yang sama berulang kali, susah tidur, sering berkemih (Carpenito, 2006).

Berdasarkan data yang diperoleh dari World Health Organization (WHO) dalam Sartika (2013), jumlah pasien dengan tindakan operasi mencapai angka peningkatan yang sangat signifikan dari tahun ke tahun. Tercatat ditahun 2011 terdapat 140 juta di seluruh rumah sakit di dunia, sedangkan pada tahun 2012 mencapai 1,2 juta jiwa, WHO dalam Sartika (2013). Berdasarkan data yang diperoleh di Rumah Sakit Umum Patuh Patut Patju Gerung yang melakukan operasi pada tahun 2015 terdapat 3078 orang, pada tahun 2016 sebesar 3138 orang dan terhitung dari bulan Januari sampai dengan Oktober 2017 terdapat 2876 orang. Dari data yang didapatkan di rumah sakit umum Patut Patuh Patju Gerung pasien yang mengalami operasi/ prosedur pembedahan mengalami peningkatan dari tahun 2015 ke 2016. Operasi/prosedur pembedahan akan memberikan suatu reaksi emosional bagi pasien. Apakah reaksi tersebut jelas atau tersembunyi, normal atau abnormal. Kecemasan dapat menimbulkan adanya perubahan secara fisik maupun psikologis yang akhirnya akan mengaktifkan saraf otonom simpatis sehingga meningkatkan denyut jantung, peningkatan tekanan darah, peningkatan frekuensi napas dan secara umum mengurangi tingkat energi pada pasien dan akhirnya dapat merugikan pasien itu sendiri karena akan berdampak pelaksanaan operasi. Terganggunya fungsi tubuh tentunya berpengaruh terhadap masalah psikologis pasien salah satu masalah yang muncul yaitu cemas.

Kecemasan perlu mendapat perhatian dan intervensi keperawatan karena keadaan emosional pasien yang akan berpengaruh kepada fungsi tubuh pasien menjelang operasi. Kecemasan yang tinggi dapat memberikan efek dalam mempengaruhi fungsi fisiologis tubuh yang ditandai dengan adanya peningkatan tekanan darah, peningkatan frekuensi nadi, peningkatan frekuensi napas (Muttaqin \& Sari, 2009). Karena dengan adanya tanda-tanda tersebut maka biasanya operasi akan ditunda oleh dokter sehingga menghambat penyembuhan penyakit pada klien. Disini peran perawat 
sangatlah diperlukan untuk melakukan intervensi kepada pasien dari pre hingga post operasi. Perawat dapat melakukan terapi-terapi seperti terapi relaksasi, distraksi, meditasi, imajinasi. Kecemasan apabila tidak diatasi akan menimbulkan masalah dan mengganggu proses operasi berlangsung atau dapat pula terjadi pembatalan operasi. Kondisi ini memerlukan suatu upaya dalam menurunkan kecemasan yang dapat dilakukan dengan mengajarkan pasien tentang teknik relaksasi, misalnya: nafas dalam, mendengarkan musik, pijat dan imajinasi terbimbing. Tindakan ini bertujuan untuk meningkatkan kendali dan percaya diri serta mengurangi stress dan kecemasan yang dirasakan. (Stuart, 2007).

Berdasarkan penelitian yang dilakukan Haskas (2013) tentang hubungan dukungan keluarga dengan tingkat kecemasan pada pasien pre operasi fraktur di ruang rawat inap Lontara II RSUP. Dr. Wahidin Sudirohusodo Makassar sebanyak 40 responden didapatkan 6 (15,0\%) responden memiliki dukungan emosional kurang baik yang mengalami cemas ringan, 23 (57,5\%) responden memiliki dukungan emosional baik mengalami cemas ringan, 5 (12,5\%) responden memiliki dukungan emosional kurang baik mengalami cemas sedang, 2 (5,0\%) responden memiliki dukungan emosional baik mengalami cemas sedang, $4(10,0 \%)$ responden memiliki dukungan emosional kurang baik mengalami cemas berat dan $0(0 \%)$ responden memiliki dukungan emosional baik mengalami cemas berat.

Kecemasan pada pasien pre operasi dapat dicegah dengan menggunakan teknik relaksasi. Beberapa jenis relaksasi di antaranya adalah relaksasi imajinasi terbimbing dan relaksasi nafas dalam. Menurut National Safety Council (2004) Relaksasi meditasi (attention-focussing exerses) yaitu teknik relaksasi untuk menjernihkan pikiran dan hanyut dalam moment yang sedang berlangsung dan relaksasi perilaku merupakan psikoterapi yang didasarkan pada pengamatan, asumsi, kepercayaan dan perilaku yang mempengaruhi emosi. National Safety Council (2003 dalam Rabi'al 2009) mengatakan, guided imagery adalah salah satu teknik distraksi yang dapat digunakan untuk mengurangi stres dan meningkatkan perasaan tenang dan damai serta merupakan obat penenang untuk situasi yang sulit dalam kehidupan.

Berdasarkan studi pendahuluan yang peneliti lakukan pada tanggal 12 Oktober 2017 di RSUD Patut Patuh Patju Gerung dengan wawancara kepada 2 perawat dan 8 pasien didapatkan hasil ada 8 pasien yang akan menjalani operasi mengatakan khawatir dengan operasi yang akan dijalaninya, pasien mengatakan merasa takut dengan operasi, susah untuk tidur dan beristirahat, tampak wajah pasien tegang dan pasien tampak gelisah, 2 diantara pasien tersebut tidak fokus menjawab pertanyaan saat wawancara. Intervensi pre operatif yang dilakukan perawat di ruangan dengan mengajarkan teknik relaksasi napas dalam untuk mengurangi kecemasan pasien. Dari intervensi yang diberikan tersebut kecemasan pasien tidak menurun. Selain teknik relaksasi napas dalam, salah satu tindakan lain untuk mengurangi kecemasan yaitu teknik relaksasi imajinasi terbimbing. Tindakan ini bertujuan 
untuk meningkatkan kendali dan percaya diri serta mengurangi stress dan kecemasan yang dirasakan. Berdasarkan uraian di atas peneliti tertarik untuk melakukan penelitian tentang Pengaruh Teknik Relaksasi Imajinasi Terbimbing Terhadap Kecemasan Pasien Pre Operasi di RSUD Patut Patuh Patju Gerung Tahun 2018.

\section{METODE}

Jenis penelitian ini adalah penelitian kuantitatif dengan pre eksperimental design yang diperluas dengan rancangan one group pre-post test. Penelitian ini akan memberikan intervensi pada subjek dengan cara melakukan observasi tingkat kecemasan pasien pre operasi (pre test) yang dilakukan minimal sehari sebelum tindakan operasi menggunakan lembar penilaian kecemasan Halimton Anxiety Rating Scale pada respendon yang sesuai dengan kriteria inklusi dan telah menandatangani informed consent. Setelah dilakukan penilain kecemasan, pasien diajarkan teknik relaksasi imajinasi terbimbing. Setelah itu dilakukan penilaian kembali tingkat kecemasan (post test) yang dilakukan 1 jam sebelum operasi.

Populasi dalam penelitian ini adalah semua pasien pre operasi dengan masalah kecemasan pre operasi di RSUD Patut Patuh Patju Gerung dengan sampel yang digunakan yaitu minnimal 30 pasien. Hipotesis penelitian ini yaitu ada pengaruh teknik relaksasi imajinasi terbimbing terhadap kecemasan pada pasien pre operasi di RSUD Patut Patuh Patju Gerung tahun 2018. Bentuk instrumen yang digunakan dalam pengumpulan data tingkat kecemasan pada pasien pre operasi menggunakan kuisioner Hamilton Anxiety Rating Scale dan cheklist teknik relaksasi imajinasi terbimbing.

\section{HASIL PENELITIAN}

Tabel 1 Distribusi Responden Menurut Kelompok usia pasien pre operasi di RSUD Patut Patuh Patju Gerung, 26 April -14 Mei 2018 (n=30)

\begin{tabular}{ccc}
\hline Usia & Jumlah & Presentase \\
\hline Dewasa Muda (18-40) & 19 & $63,33 \%$ \\
\hline Dewasa Pertengahan (40-60) & 10 & $33,33 \%$ \\
\hline Dewasa Tua (60 tahun keatas) & 1 & $3,33 \%$ \\
\hline Total & 30 & $100 \%$ \\
\hline
\end{tabular}

Berdasarkan tabel diatas dapat disimpulkan bahwa berdasarkan usia responden terbanyak adalah responden yang berada pada usia dewasa muda (18-40 tahun) sebanyak 19 orang $(63,33 \%)$ dan dewasa tua sebanyak 1 orang $(3,33 \%)$.

Tabel 2 : Distribusi Responden Menurut jenis kelamin pasien pre operasi di RSUD Patut Patuh Patju Gerung 26 April -14 Mei 2018 (n=30)

\begin{tabular}{|c|c|c|}
\hline Jenis kelamin & Jumlah & Presentase \\
\hline Laki-laki & 15 & $50 \%$ \\
\hline Perempuan & 15 & $50 \%$ \\
\hline & 30 & $100 \%$ \\
\hline
\end{tabular}


Berdasakan tabel diatas dapat disimpulkan bahwa jumlah responden jenis kelamin laki-laki dan perempuan seimbang yaitu masing-masing 15 (50\%) orang laki-laki dan 15 (50\%) orang perempuan.

Tabel 3 : Distribusi Responden berdasarkan tingkat pendidikan pasien pre operasi di RSUD Patut Patuh Patju Gerung, 26 April -14 Mei 2018 (n=30)

\begin{tabular}{|c|c|c|}
\hline Tingkat pendidikan & Jumlah & Presentase \\
\hline Tidak Sekolah & 3 & $10 \%$ \\
\hline Pendidikan Dasar & 12 & $40 \%$ \\
\hline Pendidikan Menengah & 11 & $36,66 \%$ \\
\hline Pendidikan Tinggi & 4 & $13,34 \%$ \\
\hline & 30 & $100 \%$ \\
\hline
\end{tabular}

Berdasarkan tabel diatas dapat disimpulkan bahwa sebagian besar responden dengan pendidikan dasar sebanyak 12 orang (40\%) dan responden yang tidak bersekolah sebanyak 3 orang $(10 \%)$.

Tabel 4 : Distribusi Responden berdasarkan pekerjaan pasien pre operasi di RSUD Patut Patuh Patju Gerung, 26 April -14 Mei 2018 (n=30)

\begin{tabular}{ccc}
\hline Pekerjaan & Jumlah & Presentase (\%) \\
\hline Tidak Bekerja & 8 & $26,67 \%$ \\
\hline Bekerja & 22 & $73,33 \%$ \\
\hline Total & 30 & $100 \%$ \\
\hline
\end{tabular}

Berdasarkan tabel diatas dapat disimpulkan bahwa sebagian besar responden sebanyak 22 orang $(73,33 \%)$ dan tidak bekerja sebanyak 8 orang $(26,67 \%)$.

Tabel 5 : Distribusi Responden berdasarkan pengalaman operasi pasien pre operasi di RSUD Patut Patuh Patju Gerung, 26 April -14 Mei 2018 (n=30)

\begin{tabular}{ccc}
\hline Pengalaman Operasi & Jumlah & Presentase (\%) \\
\hline Pernah & 12 & $40 \%$ \\
\hline Tidak Pernah & 18 & $60 \%$ \\
\hline Total & 30 & $100 \%$ \\
\hline
\end{tabular}

Berdasarkan tabel diatas dapat disimpulkan bahwa sebagian besar responden belum pernah menjalani operasi sebanyak 18 orang $(60 \%)$ dan responden yang pernah menjalani operasi sebanyak 12 orang $(40 \%)$.

Tabel 6 : Distribusi responden berdasarkan tingkat kecemasan sebelum dan sesudah dilakukan Teknik relaksasi imajinasi terbimbing pada pasien pre operasi di RSUD Patut Patuh Patju Gerung, 26 April -14 Mei 2018 (n=30)

\begin{tabular}{lcc}
\hline \multirow{2}{*}{ Tingkat kecemasan } & \multicolumn{2}{c}{ Jumlah $(\%)$} \\
\cline { 2 - 3 } & Sebelum & Sesudah \\
\hline Cemas ringan & 0 & $20(66,67 \%)$ \\
\hline Cemas Sedang & $20(66,67 \%)$ & $10(33,33 \%)$ \\
\hline Cemas Berat & $10(33,33 \%)$ & 0
\end{tabular}




\begin{tabular}{lcc}
\hline Total & $30(100 \%)$ & $30(100 \%)$ \\
\hline Mean & 25,67 & 18,93 \\
\hline SD & 2,746 & 2,716 \\
\hline
\end{tabular}

Berdasarkan tabel diatas dapat disimpulkan bahwa sebelum dilakukan teknik relaksasi imajinasi terbimbing sebagian besar tingkat kecemasan responden pre operasi adalah berada pada tingkat kecemasan sedang sebanyak 20 responden $(66,67 \%)$ dan setelah dilakukan tindakan teknik relaksasi imajinasi terbimbing memperlihatkan bahwa sebagian besar tingkat kecemasan responden pre operasi adalah mengalami perubahan tingkat kecemasan yang berada pada tingkat kecemasan ringan yaitu sebanyak 20 responden $(66,67 \%)$

Tabel 7: Distribusi analisis pengaruh teknik relaksasi imajinasi terbimbing terhadap kecemasan pada pasien pre operasi di RSUD Patut Patuh Patju Gerung 26 April14 Mei $2018(n=30)$

\begin{tabular}{llll}
\hline Parameter & Mean (n) & SD & $\begin{array}{l}\rho \\
\text { value }\end{array}$ \\
\hline Pre test & $25,67(30)$ & 2,746 & 0,000 \\
\cline { 1 - 3 } Post test & $18,93(30)$ & 2,716 & \\
\hline
\end{tabular}

Berdasarkan perhitungan dengan uji wilcoxon pada sistem komputerisasi SPSS, untuk perubahan tingkat kecemasan sebelum dan sesudah dilakukan teknik relaksasi imajinasi terbimbing dengan analisis statistik diperoleh nilai $\rho=0,000$ yang artinya $\rho<\alpha(\alpha=0,05)$, maka Ho ditolak dan H1 diterima yang berarti bahwa ada pengaruh teknik relaksasi imajinasi terbimbing terhadap tingkat kecemasan pada pasien pre operasi di RSUD Patut Patuh Patju Gerung Tahun 2018.

\section{PEMBAHASAN}

Hasil penelitian yang dilakukan terhadap 30 responden pasien pre operasi menunjukkan sebagian besar responden mengalami kecemasan sedang 20 responden $(66,67 \%)$ dan kecemasan berat 10 responden (33,33\%). Hal tersebut sesuai dengan penelitian yang dilakukan oleh Dino A. (2013) yang mengemukakan bahwa sebagian besar responden yang akan dilakukan operasi mengalami kecemasan sedang yaitu 52,7\% dan 47,3\% mengalami kecemasan berat. Munculnya kecemasan menjelang operasi adalah hal yang wajar. Hal ini sesuai dengan penjelasan Potter dan Perry (2005) bahwa respon psikologi yang biasanya terjadi pada pasien pre operasi yaitu kecemasan. Tindakan operasi berpotensi menimbulkan kecemasan. Pengalaman operasi sebelumnya juga berpengaruh terhadap tingkat kecemasan pasien. Hal ini ditunjukkan oleh hasil penelitian ini bahwa sebagan besar $18(60 \%)$ dari $30(100 \%)$ responden yang belum pernah memiliki pengalaman operasi cenderung memiliki tingkat kecemasan yang lebih tinggi. Kecemasan yang terjadi berhubungan dengan nyeri, kemungkinan cacat, menjadi bergantung dengan orang lain dan mungkin kematian. Hal ini juga didukung oleh teori Faradisi (2012) yang mengatakan tindakan pembedahan merupakan pengalaman 
yang sulit bagi semua pasien. Maka sering kali pasien menunjukkan sikap yang berlebihan dengan kecemasan yang mereka alami.

Menurut Stuart (2007) mengatakan bahwa tingkat kecemasan seseorang berbeda-beda meskipun menghadapi permasalahan yang sama, tetapi kecemasan tersebut ada beberapa tingkat atau level yaitu, ringan, sedang, normal dan panik. Hal ini didukung oleh Ibrahim (2012) bahwa pasien yang akan menjalani operasi umumnya mengalami kecemasan yang berbeda-beda dari tingkat ringan hingga berat.

Banyaknya responden yang mengalami kecemasan sedang dibandingkan dengan kecemasan berat dikarenakan adanya pengalaman operasi sebelumnya dan adanya pikiran positif akan kesembuhannya serta semangat untuk sehat dalam diri responden. Dalam penelitian ini terdapat 12 (40\%) responden yang sebelumnya memiliki pengalaman operasi dan $18(60 \%)$ responden sisanya tidak memiliki pengalaman operasi. Hal ini sehubungan dengan mekanisme koping yang cukup baik yang dimiliki oleh tiap responden. Berbedanya tingkat kecemasan responden bisa disebabkan persepsi yang berbeda terhadap stresor, tergantung pada somatopsikososial orang tersebut.

Menurut Potter \& Perry (2010) perubahan dari teknik relaksasi yaitu: menurunkan tekanan darah, menurunkan frekuensi jantung, mengurangi ketegangan otot, meningkatkan gelombang alfa otak, yang terjadi ketika klien sadar, tidak memfokuskan perhatian dan rileks, meningkatkan konsentrasi, memperbaiki kemampuan untuk mengatasi stressor.

Dari hasil penelitian menunjukkan setelah dilakukan teknik relaksasi imajinasi terbimbing diperoleh 20 responden $(66,67 \%)$ dengan kecemasan ringan dan 10 responden $(33,33 \%)$ dengan kecemasan sedang. Nilai rata-rata kecemasan setelah dilakukan teknik relaksasi imajinasi terbimbing yaitu 18,93 .

Setelah dilakukan teknik relaksasi imajinasi terbimbing, tingkat kecemasan pada pasien pre operasi mengalami penurunan yang signifikan. Rata-rata kecemasan responden sebelum dilakukan teknik relaksasi imajinasi terbimbing sebesar 25,67 menjadi 18,93 setelah dilakukan teknik relaksasi imajinasi terbimbing. Hasil pengujian hipotesis $(\rho<0,05)$ membuktikan teknik relaksasi imajinasi terbimbing secara signifikan mampu menurunkan tingkat kecemasan pasien.

Relaksasi merupakan metode yang efektif untuk mengatasi nyeri dan rasa cemas. Relaksasi yang sempurna dapat mengurangi ketegangan otot, kejenuhan, dan ansietas. Tiga hal utama yang diperlukan dalam tehnik relaksasi adalah posisi klien yang tepat, pikiran yang beristirahat, dan lingkungan yang tenang. Hasil penelitian ini didukung oleh penelitian yang dilakukan oleh Dino \& Sri (2013) di rumah sakit umum daerah RA Kartini Jepara meneliti efektifitas teknik relaksasi imajinasi terbimbing dan nafas dalam terhadap penurunan kecemasan pada pasien pre operasi. Hasilnya menunjukkan Hasil penelitian ini memberikan gambaran bahwa responden yang diberi tindakan teknik relaksasi imajinasi terbimbing dan nafas dalam mengalami penurunan kecemasan. Dari hasil penelitian relaksasi imajinasi terbimbing diperoleh rata-rata penurunan kecemasan sebesar 9,07, lebih tinggi dibandingkan dengan sesudah dilakukan terapi nafas dalam dengan rata-rata sebesar 8,3 . 
Hal ini didukung pula oleh penelitian yang dilakukan oleh Reliana (2015) dengan judul penelitian teknik guided imagery terhadap tingkat kecemasan penderita kanker serviks, yang dilakukan pada 14 responden. Berdasarkan hasil penelitian bahwa tingkat kecemasan pada penderita kanker serviks sebelum dilakukan teknik guided imagery sebagian besar mengalami kecemasan sedang yaitu sebanyak 9 orang (64\%) sedangkan paling sedikit penderita kanker serviks mengalami kecemasan ringan yaitu sebanyak 5 orang (36\%) dari 14 responden.

Dalam penelitian ini kecemasan yang dialami setiap responden tentunya berbeda-beda, banyak faktor yang mempengaruhi kecemasan pada setiap responden mulai dari faktor usia, jenis kelamin, tingkat pendidikan, pekerjaan dan pengalaman operasi. Sebagian dari jumlah responden pada penelitian ini tidak memiliki pengalaman operasi dan cenderung memiliki tingkat kecemasan yang berat. Dari teknik relaksasi imajinasi terbimbing yang diberikan kepada responden terdapat perubahan tingkat kecemasan. Responden mengatakan merasa lebih tenang, nyaman dan dapat mengontrol rasa cemasnya setelah melakukan teknik relaksasi imajinasi terbimbing. Hal ini membuktikan bahwa teknik relaksasi imajinasi terbimbing berpengaruh terhadap tingkat kecemasan pasien pre operasi.

\section{KESIMPULAN}

Berdasarkan hasil penelitian dan pembahasan maka peneliti mengambil kesimpulan bahwa Kecemasan pasien pre operasi sebelum dilakukan teknik relaksasi imajinasi terbimbing di RSUD Patut Patuh Patju Gerung Tahun 2018 sebagian besar berada pada kategori kecemasan sedang. Kecemasan pre operasi setelah dilakukan teknik relaksasi imajinasi terbimbing di RSUD Patut Patuh Patju Gerung Tahun 2018 sebagian besar berada pada kategori kecemasan ringan. Ada pengaruh teknik relaksasi imajinasi terbimbing terhadap kecemasan pada pasien pre operasi di RSUD Patut Patuh Patju Gerung Tahun 2018.

Diharapkan bagi institusi pelayanan dapat membuat standar operasional (SOP) tentang teknik relaksasi imajinasi terbimbing dan menghimbau perawat untuk memberikan teknik relaksasi imajinasi terbimbing pada pasien pre operasi sebagai salah satu nonfarmakologi dalam mengatasi kecemasan pasien. Bagi peneliti lain dapat menggunakan variabel-variabel lain yang dapat digunakan untuk mengukur penurunan penurunan kecemasan pasien preoperasi dengan menggunakan responden penelitian yang lebih banyak lagi dengan desain penelitian yang lebih baik sehingga akurasi hasil dapat lebih maksimal. 


\section{DAFTAR PUSTAKA.}

Carpenito. 2006. Buku Saku Diagnosa Keperawatan. Alih Bahasa Asih Yasmis ; Editor Bahasa Indonesia, Monika Ester, Edisi 10, Jakarta: EGC.

Dino dan Sri. 2013. Efektifitas Teknik Relaksasi Imajinasi Terbimbing Dan Nafas Dalam Terhadap Penurunan Kecemasan Pada Pasien Pre Operasi Di RSUD Kartika Jepara. Jurnal Keperawatan.

Potter dan Perry. 2010. Fundamental keperawatan buku 3. Edisi 7. Jakarta: Salemba Medika.

Potter, P.A. \& Perry, A.G. 2005. Buku Ajar Fundamental Keperawatan, Edisi 4. Jakarta: EGC. 